\title{
The extraction of zinc and other minor metals from concentrated ammonium chloride solutions with D2EHPA and Cyanex 272(*)
}

\begin{abstract}
S. Amer ${ }^{(*)}$ and A. Luis ${ }^{(*)}$
Resumen A comparative study is made of the extractants D2EHPA and Cyanex 272 for the zinc and minor metal extraction from aqueous concentrated ammonium chloride solutions, as those of the leaching liquors of the CENIM-LNETI process. Extraction equilibrium data for zinc are presented as extraction isotherms at constant $\mathrm{pH}$ and at a temperature of $50^{\circ} \mathrm{C}$. Zinc extraction and coextraction of minor metal ions as $\mathrm{Cu}, \mathrm{Ca}, \mathrm{Pb}, \mathrm{Mg}, \mathrm{Cd}, \mathrm{Co}, \mathrm{Ni}$ and $\mathrm{Hg}$ are studied. Mercury does not extract from concentrated ammonium chloride solutions. Cyanex 272 shows a better selectivity for zinc with regard to the minor metals than D2EHPA, which is especially remarkable for calcium, the most coextracted element by D2EHPA. Nickel and cadmium coextraction is negligible for both extractants. The possible use of the Cyanex 272 as an alternative to D2EHPA is considered.
\end{abstract}

Keywords: Zinc. Bis(-2-ethylhexil) phosphoric acid. Cyanex 272. Solvent extraction. Concentrated ammonium chloride solutions.

\section{Extracción del cinc y otros metales minoritarios de soluciones concentradas de cloruro amónico con D2EHPA y Cyanex 272}

\begin{abstract}
Se realiza un estudio comparativo del comportamiento del D2EHPA y del Cyanex 272 durante la extracción del cinc y otros metales minoritarios de soluciones acuosas concentradas de cloruro amónico, como las de las soluciones de lixiviación del proceso CENIM-LNETI. Se presentan los datos de equilibrio de extracción del cinc en forma de isotermas de extracción a una temperatura de $50{ }^{\circ} \mathrm{C}$ y $\mathrm{pH}$ constante y se estudia la coextracción de los metales minoritarios $\mathrm{Cu}, \mathrm{Ca}, \mathrm{Pb}, \mathrm{Mg}, \mathrm{Cd}$, $\mathrm{Co}, \mathrm{Ni}$ y $\mathrm{Hg}$. El mercurio no se extrae de las soluciones concentradas de cloruro amónico. La selectividad del Cyanex 272 para el cinc respecto de esos metales minoritarios es mejor que la del D2EHPA, siendo verdaderamente notable para el calcio, que es la impureza que más se coextrae con el D2EHPA. La coextracción de níquel y de cadmio es muy pequeña para ambos extractantes. Se considera la posibilidad del uso alternativo del Cyanex 272 en lugar del D2EHPA.
\end{abstract}

Palabras clave: Cinc. Ácido di(-2-etilhexil) fosfórico. Cyanex 272. Extracción con disolventes. Solución concentrada de cloruro amónico.

\section{INTRODUCTION}

The use of hydrometallurgical methods for the recovery of metals has made possible to process low grade ores. Because of that, new techniques have been developed like the solvent extraction, which improves the recovery, separation and

\footnotetext{
(•) Trabajo recibido el día 3 de abril de 1995

(*) Centro Nacional de Investigaciones Metalúrgicas. (CSIC). Avda. de Gregorio del Amo, 8. 28040 Madrid (España).
}

purification of metal values from the leaching liquors. Among the reagents used for the solvent extraction of metals the organophosphorous extractants have played an important role. The bis (-2-ethylhexyl)phosphoric acid (D2EHPA) is the most characteristic and used of the organophosphoric acids. This extractant has been applied in many processes to recover metal values. Some of these processes have been described for the recovery of zinc (1). D2EHPA has also been used in many basic research studies with many metallic ions.

Some other types of acidic organophosphorous extractants, besides the organophosphoric acids, 
(RO) ${ }_{2} \mathrm{PO}_{2} \mathrm{H}$, have been proposed, corresponding to the phosphonic, (RO)(R) $\mathrm{PO}_{2} \mathrm{H}$, and to the phosphinic acids, $(\mathrm{R})_{2} \mathrm{PO}_{2} \mathrm{H}$, in which $R$ refers to alkyl radicals. All three types of extractants have different structures in relation to the nature and number of bonds between the phosphorus atom and the alkyl radicals, that is, if they are bonded through an oxygen atom, $P-O-R$, or by direct $P-R$ bonds. Recently, American Cyanamid Co. has proposed the bis(2,4,4'trimethylpenthyl)phosphinic acid, under the trade name of Cyanex 272. At present, this extractant is known by its application to the cobalt and nickel separation (2 and 3), of which some plants are now in operation (4). Cyanex 272 has been studied comparatively to D2EHPA and PC-88A (Daihachi Chemical Co.) for cobalt and nickel separation (2 and 5-7). Cyanex 272 has also been used for the separation of zirconium and hafnium (8) and of the rare earths (9-11) and for the recovery of gallium (12).

The structure and the degree of branching have great influence on the stability of the metal complexes and also on the selectivity of the Cyanex 272 (6 and 7). These acidic dialkylphosphorous extractants are monobasic acids and their acidic character is also influenced by their structure, the dialkylphosphoric (D2EHPA) and the dialkylphosphonic (PC-88A) are stronger acids than the dialkylphosphinic (Cyanex 272) (6). Another important characteristic of the Cyanex 272 is its poor extraction properties for calcium (2), which is much more extracted by D2EHPA and PC-88A and of which can be taken advantage for calcium removal.

In this paper a comparative study of D2EHPA and Cyanex 272 has been made for the zinc extraction from aqueous concentrated ammonium chloride solutions, as those existing in the leaching liquors of the CENIM-LNETI process (13-16) for complex sulphide concentrates and other secondary raw materials. The recovery of zinc in this process is performed with D2EHPA (17). These leaching solutions, besides zinc as a major metal component, contain some other minor metal ion impurities and among them calcium. The solvent extraction flowsheet has two scrubbing stages with zinc chloride solutions to remove calcium and other metal impurities from the zinc loaded extract. Cyanex 272 is a good extractant for zinc, having a high $\mathrm{Zn} / \mathrm{Ca}$ selectivity, for which it has been studied as a possible alternative to D2EHPA.

\section{EXPERIMENTAL}

Batch extraction tests, as previously described (18), have been performed for $30 \mathrm{~min}$ in stirred glass cells provided with a jacket for hot water circulation. Ammonia was slowly added when stirring to the appropriate volumes of each phase up to the desired $\mathrm{pH}$. Temperature was kept constant at $50{ }^{\circ} \mathrm{C}$ in all experimental work performed.

Aqueous phases of zinc or zinc and other minor metal ions in concentrated ammonium chloride solutions were prepared, in which total chloride concentration was adjusted to a value of 6 molal. Organic phases were formed by an extractant, D2EHPA or Cyanex 272, of $~ 0.6 \mathrm{M}(20 \% \mathrm{v} / \mathrm{v})$ concentration diluted with kerosene 200/260 and modified by $8 \%$ isodecanol.

Analytical grade reagents were used to prepare aqueous solutions. D2EHPA extractant came from Daihachi Chemical Co., named DP-8R and had a minimum purity of $95 \%$. The Cyanex 272 sample used was kindly provided by Cyanamid Ibérica S.A. and Kerosene 200/260 by Campsa and corresponds to a distillation fraction between 190 and $260{ }^{\circ} \mathrm{C}$ with a flash point of $60{ }^{\circ} \mathrm{C}$ and an aromatic content about $10 \%$. The isodecanol used initially came from Riedel-de-Haën and later from Hoescht. Table I shows some physical and chemical characteristics of the extractants (19-21).

\subsection{Methods of Analysis}

Zinc has been titulated by complexometric titration with EDTA and eriochrome black as indicator. In multiple mixtures of zinc and other minor elements, all the metals have been analyzed by atomic absorption spectrometry and in binary mixtures of zinc and one minor metal, only the minor metal was determined by atomic absorption and its value deduced from the total metal concentration by complexometric titration to obtain the zinc concentration. As certain minor metals $(\mathrm{Cu}, \mathrm{Co}$ and $\mathrm{Ni}$ ) interferred with the indicator eriochrome black, murexide was used instead. Metal concentrations in the organic phases were determined in the same way as in the aqueous phase

TABLA I.- Physical and chemical properties of the extractants

TABLE I.-Propiedades físicas y químicas de los extractantes

\begin{tabular}{|l|l|l|l|l|}
\hline Extractant & $\begin{array}{l}\text { Viscosity, } \\
\mathrm{Cp}\end{array}$ & $\begin{array}{l}\text { Specific } \\
\text { gravity }\end{array}$ & $\begin{array}{l}\text { Dimer, } \\
\log K 2 \\
(19)^{*}\end{array}$ & $\begin{array}{l}\mathrm{pKa} \\
(19)^{*}\end{array}$ \\
\hline $\begin{array}{l}\text { D2EHPA } \\
(20)\end{array}$ & $53\left(20^{\circ} \mathrm{C}\right)$ & $0.977\left(20^{\circ} \mathrm{C}\right)$ & 4.5 & 1.5 \\
\hline $\begin{array}{l}\text { Cyanex } 272 \\
(21)\end{array}$ & $\begin{array}{l}184\left(21^{\circ} \mathrm{C}\right) \\
38\left(50^{\circ} \mathrm{C}\right)\end{array}$ & $0.92\left(24^{\circ} \mathrm{C}\right)$ & 3 & 3.2 \\
\hline
\end{tabular}

* Extractants diluted in Kerosene. 
after metal stripping with sulphuric acid $(\sim 3-4 \mathrm{~N})$. Chlorides were titrated by the Volhard method.

D2EHPA concentration in the organic phase was determined by volumetric titration in an alcoholic solution with thymol blue as indicator. A standard $0.1 \mathrm{~N} \mathrm{NaOH}$ in a $75 \%$ isopranol-25\% water solution was used. The organic sample was conveniently diluted with an alcohol, as isopropanol or ethanol. The value obtained with this method was checked with the obtained by zinc extraction at saturation with a good agreement. Titrimetric determinations of Cyanex 272 using thymol blue indicator, with the above described method, gave erroneous values, slightly lower than those of real concentrations and because of that a potentiometric titration in an alcoholic medium, as explained before, was performed by using both a glass and a reference $(\mathrm{Ag} / \mathrm{AgCl})$ electrode. The purity of the Cyanex 272 sample used was estimated from potentiometric titration results and showed to be $88.25 \%$. A value of this purity reported in the literature (10) was estimated as 88 $\%$, being impurified by two unspecified phosphine oxides in proportions of 5 and $7 \%$ (10). Some other values for different samples have been reported.

\section{RESULTS}

Synthetic aqueous solutions were prepared with approximately the same concentrations of zinc and chlorides to that of the leaching solutions of the CENIM-LNETI process. A concentration of about $24 \mathrm{~g} / \mathrm{l} \mathrm{Zn}$ was used for the Cyanex 272 extraction equilibrium data determination. Figures 1 and 2 show the respective zinc extraction equilibrium concentrations for D2EHPA, previously determined, and Cyanex 272 in both phases corresponding to the extraction isotherms obtained at constant $\mathrm{pH}$ for different $\mathrm{pH}$ values and at a temperature of $50{ }^{\circ} \mathrm{C}$. For D2EHPA ( $\mathrm{pH}$ range, 2-6) a $\mathrm{pH}=2$ is reached, at which the system is still operative (the raffinate $\mathrm{pH}$ value is about 2) (17). For Cyanex 272 (pH range, 3-6) zinc extraction at $\mathrm{pH} 2$ has a lower magnitude.

Figure 3 shows the variation of zinc extraction with the aqueous phase $\mathrm{pH}$ (at a O/A phase ratio 1) for both extractants. As it can be observed there is a $\mathrm{pH}$ zone for which zinc extraction has a maximum value, the extraction decreasing afterwards for higher $\mathrm{pH}$. It is important to compare the extraction behaviour of the two extractants with regard to zinc and other minor metal ions from concentrated ammonium chloride solutions. Figures 4 to 9 and table II show zinc extraction and minor metal coextraction for D2EHPA and Cyanex 272. Figure 4 represents the extraction of zinc, copper, lead and calcium by these two extractants from

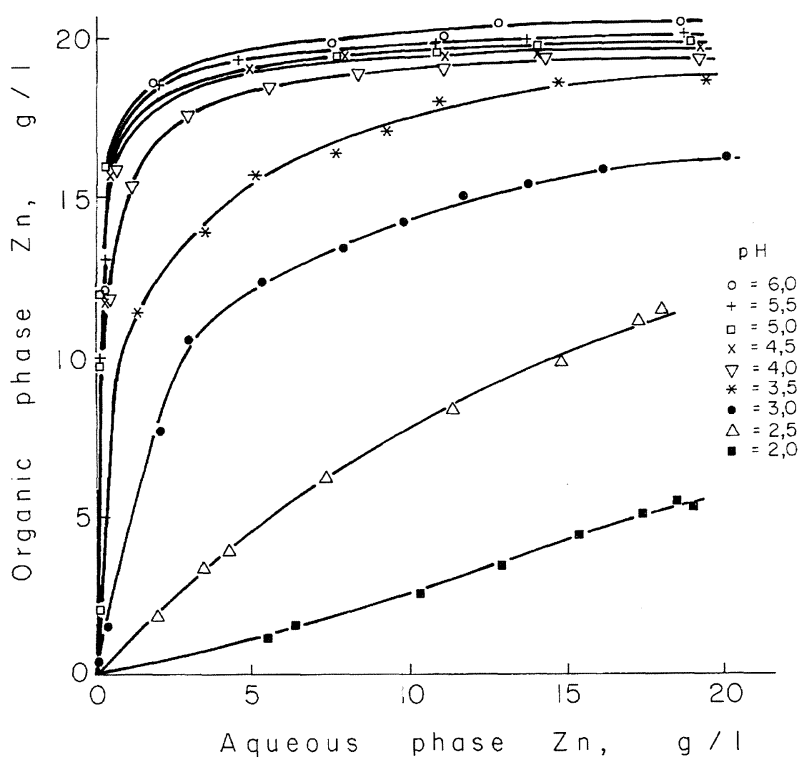

FIG. 1.- Zinc extraction isotherms by D2EHPA at different $\mathrm{pH}$. Organic phase: $0.6 \mathrm{M} \mathrm{D} 2 \mathrm{EHPA}$ in kerosene 200/260 and $8 \%$ isodecanol. Initial aqueous phase composition: $\mathrm{Zn}=24.29 \mathrm{~g} / \mathrm{l}, \mathrm{Cl}^{-}$ $=173.7 \mathrm{~g} / \mathrm{l}$ in a concentrated ammonium chloride solution. Temperature, $50^{\circ} \mathrm{C}$. (18 and 23$)$.

FIG. 1.- Isotermas de extracción de cinc con D2EHPA a diferentes pHs. Fase orgánica: $\sim 0,6 \mathrm{M}$ D2EHPA en queroseno 200/260 y $8 \%$ de isodecanol. Composición inicial de la fase acuosa: $\mathrm{Zn}=$ 24,29 $\mathrm{g} / \mathrm{l}, \mathrm{Cl}^{-}=173,7 \mathrm{~g} / \mathrm{l}$ en una solución concentrada de cloruro amónico. Temperatura, $50{ }^{\circ} \mathrm{C}$. (18 y 23).

solutions at similar concentrations to the leaching solutions of complex sulphides. The following figures show the metal extraction in binary mixtures, $\mathrm{Zn}+\mathrm{M}$, for zinc concentrations about 20 $\mathrm{g} / \mathrm{l} \mathrm{n}$ and of $1 \mathrm{~g} / \mathrm{l}$ of the minor metal, $M$, except for copper and calcium, which were about $2 \mathrm{~g} / \mathrm{l}$. Metals tested were copper (Fig. 5), calcium (Fig. 6), magnesium (Fig. 7), cobalt (Fig. 8), nickel (Fig. 9) and cadmium (Table II). Mercury was tested by direct extraction from a mercury solution in concentrated ammonium chloride $(\mathrm{Hg}=2 \mathrm{~g} / \mathrm{l}$ and $\left.\mathrm{Cl}^{-}=173 \mathrm{~g} / \mathrm{l}\right)$ in the absence of zinc at $\mathrm{pH} 4$ and 6 for D2EHPA and pH 6 for Cyanex 272. No mercury was detected in the organic phase for none of the extractants.

These tests are useful to know the behaviour of the minor metal ions in the leaching solutions when zinc is extracted. Complex sulphide contains zinc, copper and lead. Calcium is not found in sulphidic concentrates used in the CENIM-LNETI process research, but originates from lime addition to the leaching solutions to remove sulphate by calcium sulphate precipitation, to avoid sulphate build up. The 


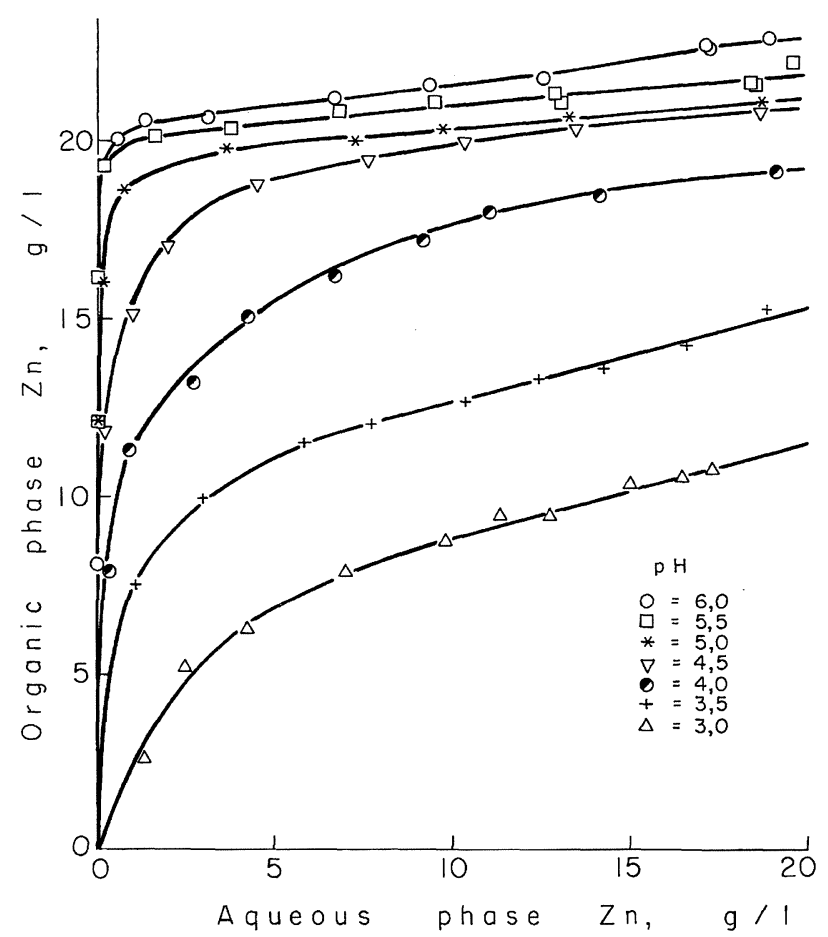

FIG. 2.-Zinc extraction isotherms by Cyanex 272 at different pHs. Organic phase: $0.6 \mathrm{M}$ Cyanex 272 in kerosene $200 / 260$ and $8 \%$ isodecanol. Initial aqueous phase composition: $\mathrm{Zn}=24.26 \mathrm{~g} / \mathrm{l} \mathrm{Cl}^{-}$ $=173.9 \mathrm{~g} / \mathrm{l}$ in a concentrated ammonium chloride solution. Temperature, $50^{\circ} \mathrm{C}$.

FIG. 2.- Isotermas de extracción de cinc con Cyanex 272 a diferentes pHs. Fase orgánica: 0,6 M Cyanex 272 en queroseno 200/260 y $8 \%$ de isodecanol. Composición inicial de la fase acuosa: $\mathrm{Zn}=$ 24,26 $\mathrm{g} / \mathrm{l}, \mathrm{Cl}^{-}=173,9 \mathrm{~g} / \mathrm{l}$ en una solución concentrada de cloruro amónico. Temperatura, $50{ }^{\circ} \mathrm{C}$.

control of sulphate by lime addition will give an additional reaction with ammonium chloride in solution

$$
\mathrm{CaO}+2 \mathrm{NH}_{4}^{+} \Leftrightarrow \mathrm{Ca}^{2+}+2 \mathrm{NH}_{3}+\mathrm{H}_{2} \mathrm{O}
$$

supplying an additional amount of ammonia to the circuit. This can be benefitial because there is a deficit of ammonia with regard to the theoretical value of 2 mols of ammonia per mol of zinc and/or copper in the leaching solutions of complex sulphide and this allows to compensate it (16).

Some secondary raw materials as metallurgical byproducts like the electric arc furnace (EAF) dusts from steel mills, which have a relatively high content of zinc oxide, can be treated successfully with the CENIM-LNETI process to recover zinc (17). The EAF dusts leaching solutions contain zinc, copper, calcium, magnesium, manganese, cadmium and an excess of ammonia, which is produced by the presence of $\mathrm{CaO}$ in that material.

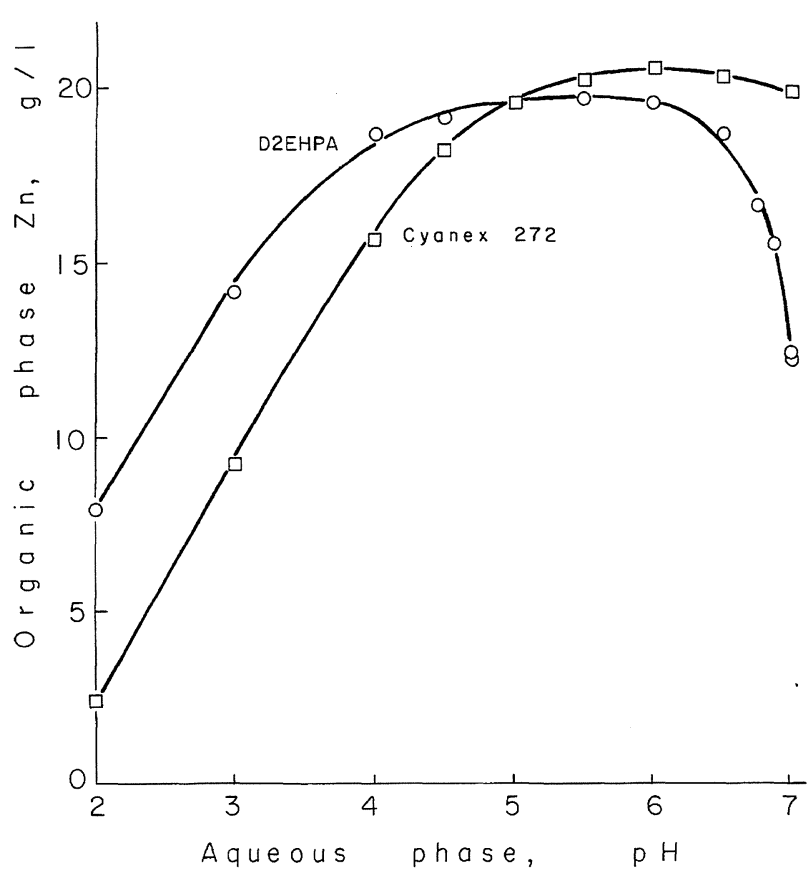

FIG. 3.- Influence of $\mathrm{pH}$ on zinc extraction by D2EHPA and Cyanex 272. Organic phase: $\sim 0.6 \mathrm{M}$ extractant in kerosene 200/260 and $8 \%$ isodecanol. Initial aqueous phase composition: $\mathrm{Zn} 23.5 \mathrm{~g} / \mathrm{l}, \mathrm{Cl}^{-}$ $=171.6$ in a concentrated ammonium chloride solution. O/A phase ratio, $\sim 1 / 1$. Temperature, $50^{\circ} \mathrm{C}$.

FIG. 3.- Influencia del pH sobre la extracción del cinc por D2EHPA y Cyanex 272. Fase orgánica: Extractante 0,6 M en queroseno 200/260 y $8 \%$ de isodecanol. Composición inicial de la fase acuosa: $\mathrm{Zn}=23,5 \mathrm{~g} / \mathrm{l}, \mathrm{Cl}^{-}=171,6 \mathrm{~g} / \mathrm{l}$ en una solución concentrada de cloruro amónico. Relación de fases O/A, 1/1. Temperatura, $50^{\circ} \mathrm{C}$.

The excess of ammonia causes damage to the extraction process and should be eliminated by neutralizing it with sulphuric acid. At the same time of the neutralization of the excess of ammonia calcium is precipitated as calcium sulphate keeping calcium concentration at a minimum level in solution. Manganese has not been tested, because it is not a harmful element for zinc electrolysis and pregnant solutions in zinc metallurgical processes have a high content of manganese (22). Besides, manganese excess can be removed during zinc electrolysis as manganese bioxide in anodic sludges. Metal impurities, such as cobalt, nickel and mercury, have been studied assuming their possible presence in some other raw materials, mainly complex sulphides from different origin.

\section{DISCUSSION OF THE RESULTS}

The solvent extraction of a metal ion by the acidic dyalkylphosphoric extractants, as that of zinc 


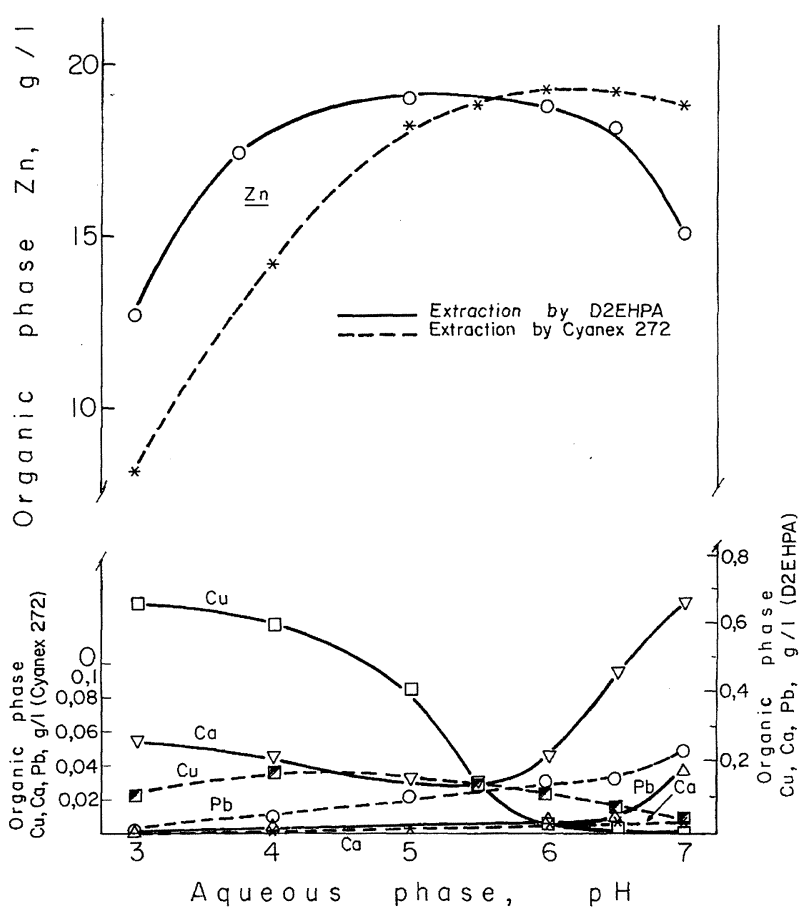

FIG. 4.- Extraction of zinc, copper, lead and calcium by D2EHPA and Cyanex 272. Organic phase: 0.6 M extractant in kerosene 200/260 and $8 \%$ isodecanol. Initial aqueous phase composition: $\mathrm{Zn}=21.4 \mathrm{~g} / \mathrm{l}, \mathrm{Cu}=2.5 \mathrm{~g} / \mathrm{l}, \mathrm{Pb}=2.4 \mathrm{~g} / \mathrm{l}, \mathrm{Ca}=0.83$ $\mathrm{g} / \mathrm{l}$ and $\mathrm{Cl}^{-}=175.8 \mathrm{~g} / \mathrm{l}$ in a concentrated ammonium chloride solution. O/A phase ratio $\sim 0.75 / 1$. Temperature, $50{ }^{\circ} \mathrm{C}$. Full line $=$ D2EHPA. Dotted line = Cyanex 272.

FIG. 4.-Extracción de cinc, cobre, plomo y calcio por D2EHPA y Cyanex 272. Fase orgánica: Extractante 0,6 M en queroseno 200/260 y $8 \%$ de isodecanol. Composición inicial de la fase acuosa: $\mathrm{Zn}=21,4 \mathrm{~g} / \mathrm{l}, \mathrm{Cu}=2,5 \mathrm{~g} / \mathrm{l}, \mathrm{Pb}=2,4 \mathrm{~g} / \mathrm{l} \mathrm{Ca}=0,83$ $\mathrm{g} / \mathrm{l}$ y $\mathrm{Cl}^{-}=175,8 \mathrm{~g} / \mathrm{l}$ en una solución concentrada de cloruro amónico. Relación de fases O/A, 0,75/1. Temperatura, $50{ }^{\circ} \mathrm{C}$. Línea de trazo continuo $=$ D2EHPA. Linea de trazos = Cyanex 272 .

by D2EHPA, can be expressed by the following extraction equilibrium between two phases (18 and 23).

$$
\begin{gathered}
\left(\mathrm{Zn}^{2+}\right)_{a}+n\left[(\mathrm{HR})_{2}\right]_{o} \Leftrightarrow\left[\mathrm{ZnR}_{2} \cdot 2(n-1) H R\right]_{o} \\
+2\left(\mathrm{H}^{+}\right)_{a}
\end{gathered}
$$

where (HR $)_{2}$ represents the dimeric form of the extractant, $a$ and $o$ subindexes refer to the aqueous and organic phases, respectively. $\mathrm{Zn}^{2+}$ ion is the major metallic component in solution, $n$ is the stoichiometric coefficient for the free non metal complex forming extractant, which depends on $\mathrm{pH}$. In ordinary conditions of the leaching solutions with a high $\mathrm{pH}(\mathrm{pH} 6$ to 7$)$ and high zinc concentrations $n$ is slightly higher than 1 . If the

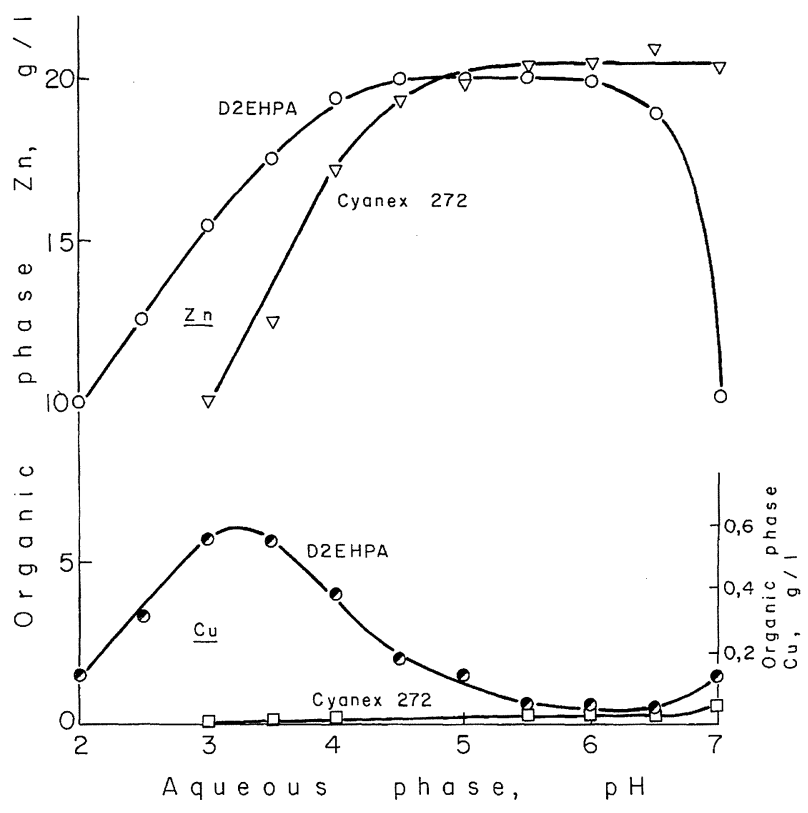

FIG. 5.- Extraction of zinc and copper by D2EHPA and Cyanex 272. Organic phase: $~ 0.6 \mathrm{M}$ extractant in kerosene $200 / 260$ and $8 \%$ isodecanol. Initial aqueous phase composition: $\mathrm{Zn}=23.4 \mathrm{~g} / \mathrm{l}, \mathrm{Cu}$ $=2.02 \mathrm{~g} / 1$ and $\mathrm{Cl}^{-}=170 \mathrm{~g} / 1$ in a concentrated ammonium chloride solution. O/A phase ratio, $\sim 0.75 / 1$. Temperature, $50^{\circ} \mathrm{C}$.

FIG. 5.- Extracción de cinc y de cobre por D2EHPA y Cyanex 272. Fase orgánica: Extractante $\sim 0,6 \mathrm{M}$ en queroseno 200/260 y $8 \%$ de isodecanol. Composición inicial de la fase acuosa: $\mathrm{Zn}=23,4$ $\mathrm{g} / \mathrm{l}, \mathrm{Cu}=2,02 \mathrm{~g} / \mathrm{l}$ y $\mathrm{Cl}^{-}=170 \mathrm{~g} / \mathrm{l}$ en una solución concentrada de cloruro amónico. Relación de fases O/A, 0,75/1. Temperatura, $50^{\circ} \mathrm{C}$.

metal concentration in the organic phase increases and no free extractant remains in it saturation is reached. This may happen when the D2EHPA loaded organic phase is scrubbed in two stages with zinc chloride solutions (17).

Some analogies about the metal extraction with dialkylphosphoric acidic extractants are expected to be found in the extraction behaviour of the acidic dialkylphosphinic extractants with divalent metals. The extracted species of zinc and other divalent metals with D2EHPA are similar to those of the bis $(2,4,4$ 'trimethylpentyl)phosphinic acid (BTMPPA, acidic dialkylphosphinic component of Cyanex 272). $\mathrm{ZnR}_{2} \cdot \mathrm{RH}$ and $\mathrm{ZnR}_{2} .2 \mathrm{RH}$ metal organic species are found in both cases (24). Therefore the extraction equilibrium [2] can also be written in the case of Cyanex 272.

Cyanex 272, as it has been said in the experimental part, is an impurified chemical and besides the BTMPPA main component there are some other impurities, that have been described as phosphine oxide species (10 and 11), and it can 


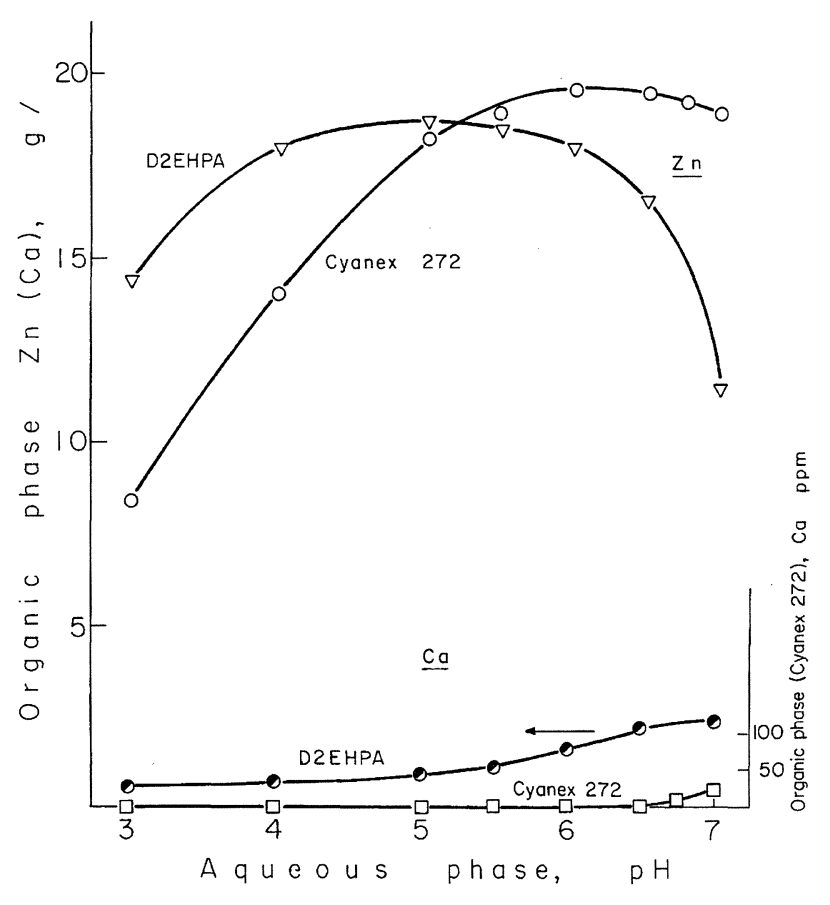

FIG. 6.- Extraction of zinc and calcium by D2EHPA and Cyanex 272. Organic phase: $\sim 0.6 \mathrm{M}$ extractant in kerosene $200 / 260$ and $8 \%$ isodecanol. Initial aqueous phase composition: $\mathrm{Zn}=20.0 \mathrm{~g} / \mathrm{l}$, $\mathrm{Ca}=1.9 \mathrm{~g} / \mathrm{l}$ and $\mathrm{Cl}^{-}=174.8 \mathrm{~g} / \mathrm{l}$ in a concentrated ammonium chloride solution. $\mathrm{O} / \mathrm{A}$ phase ratio, $\sim 0.75 / 1$. Temperature, $50^{\circ} \mathrm{C}$.

FIG. 6.- Extracción de cinc y de calcio por D2EHPA y Cyanex 272. Fase orgánica: Extractante $\sim 0,6 \mathrm{M}$ en queroseno 200/260 y $8 \%$ de isodecanol. Composición inicial de la fase acuosa: $\mathrm{Zn}=20,0$ $\mathrm{g} / \mathrm{l}, \mathrm{Ca}=1,9 \mathrm{~g} / \mathrm{l}$ y $\mathrm{Cl}^{-}=174,8 \mathrm{~g} / \mathrm{l}$ en una solución concentrada de cloruro amónico. Relación de fases O/A, 0,75/1. Temperatura, $50^{\circ} \mathrm{C}$.

presumably be supposed, at least partially, as tri(2,4,4'trimethylpentyl)phosphine oxide. The consequence of the presence of phosphine oxide species in an appreciable amount, almost $12 \%$ of the components of Cyanex 272, is the possible formation of an adduct with the metal extracted species, as it has been shown for the rare earths (11). This could explain some anomalous results in the extraction of zinc at high $\mathrm{pH}$ and at high aqueous/organic phase ratios that can not be explained by a simple $\mathrm{Zn}-\mathrm{H}^{+}$exchange with the acidic Cyanex 272 extractant.

The use of concentrated ammonium chloride solutions as a leaching medium for sulphides and oxides is based, besides the chloride role, on the singularity of ammonium ion in generating ammonia (13 and 16). The ammonia is fixed as metal ammine complexes of formula $\mathrm{M}\left(\mathrm{NH}_{3}\right)_{\mathrm{i}}{ }^{2+}$, being $i=1$ to 4 , and will provide the necessary neutralization capacity for the $\mathrm{H}^{+}$ions released

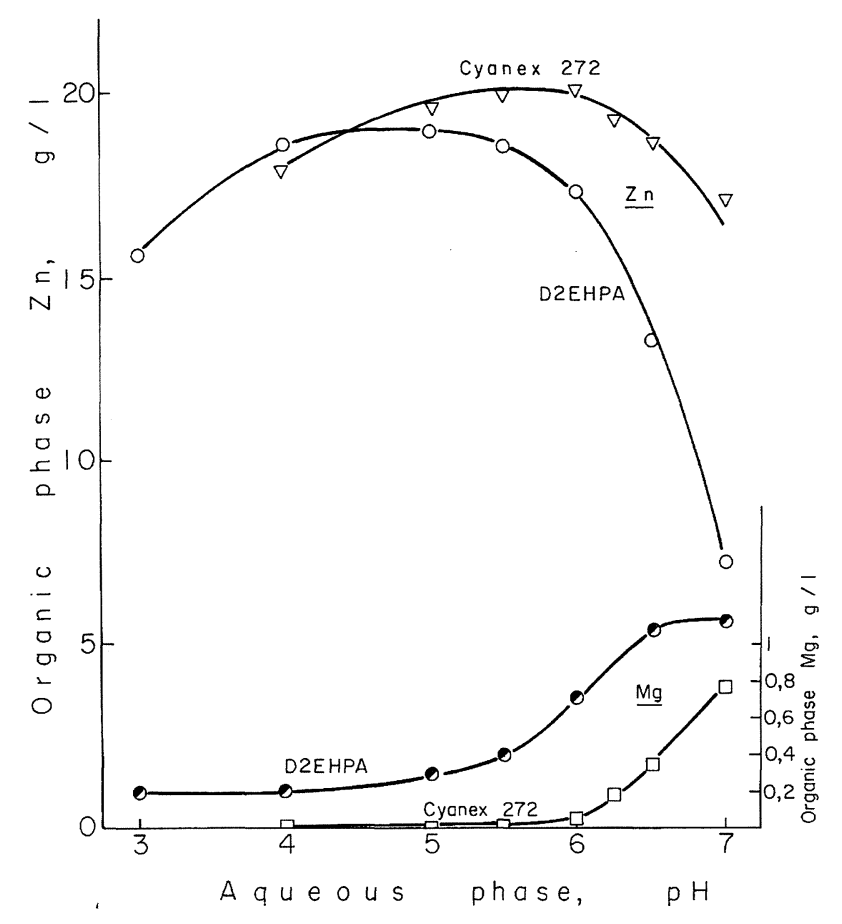

FIG. 7.- Extraction of zinc and magnesium by D2EHPA and Cyanex 272. Organic phase: $\sim 0.6 \mathrm{M}$ extractant in kerosene $200 / 260$ and $8 \%$ isodecanol. Initial aqueous phase composition: $\mathrm{Zn}=18.8 \mathrm{~g} / \mathrm{l}$, $\mathrm{Mg}=1.0 \mathrm{~g} / \mathrm{l}$ and $\mathrm{Cl}^{-}=174 \mathrm{~g} / \mathrm{l}$ in a concentrated ammonium chloride solution. O/A phase ratio, $\sim 0.75 / 1$. Temperature, $50{ }^{\circ} \mathrm{C}$.

FIG. 7.-Extracción de cinc y de magnesio por D2EHPA y Cyanex 272. Fase orgánica: Extractante $\sim 0,6 \mathrm{M}$ en queroseno 200/260 y $8 \%$ de isodecanol. Composición inicial de la fase acuosa: $\mathrm{Zn}=18,8$ $\mathrm{g} / \mathrm{l}, \mathrm{Mg}=1,0 \mathrm{~g} / \mathrm{l}$ y $\mathrm{Cl}^{-}=174 \mathrm{~g} / \mathrm{l}$ en una solución concentrada de cloruro amónico. Relación de fases O/A, 0,75/1. Temperatura, $50^{\circ} \mathrm{C}$.

during the solvent extraction of metallic ions by acidic extractants from pregnant leaching solutions as shown in [2]. This is particularly important when zinc, which is the main metal component of the leaching solutions, is extracted, otherwise the extraction would be stopped by the presence of a certain $\mathrm{H}^{+}$ion concentration.

The comparison of the zinc extraction curves for both extractants in figure 3 shows that the $\mathrm{pH}$ range for zinc extraction by Cyanex 272 is slightly displaced towards higher $\mathrm{pH}$ in relation to that of D2EHPA, and the maximum zinc extraction corresponds to $\mathrm{pH} \sim 6$, while for D2EHPA this maximum is placed at a $\mathrm{pH}$ between 5 and 6 . For higher $\mathrm{pH}$ values $(\mathrm{pH} \sim 7)$ zinc extraction decreases somewhat for D2EHPA, but for Cyanex 272 still keeps a relatively high value, even in the presence of chloride ions at a high concentration and ammonia at this $\mathrm{pH}$, which will influence 


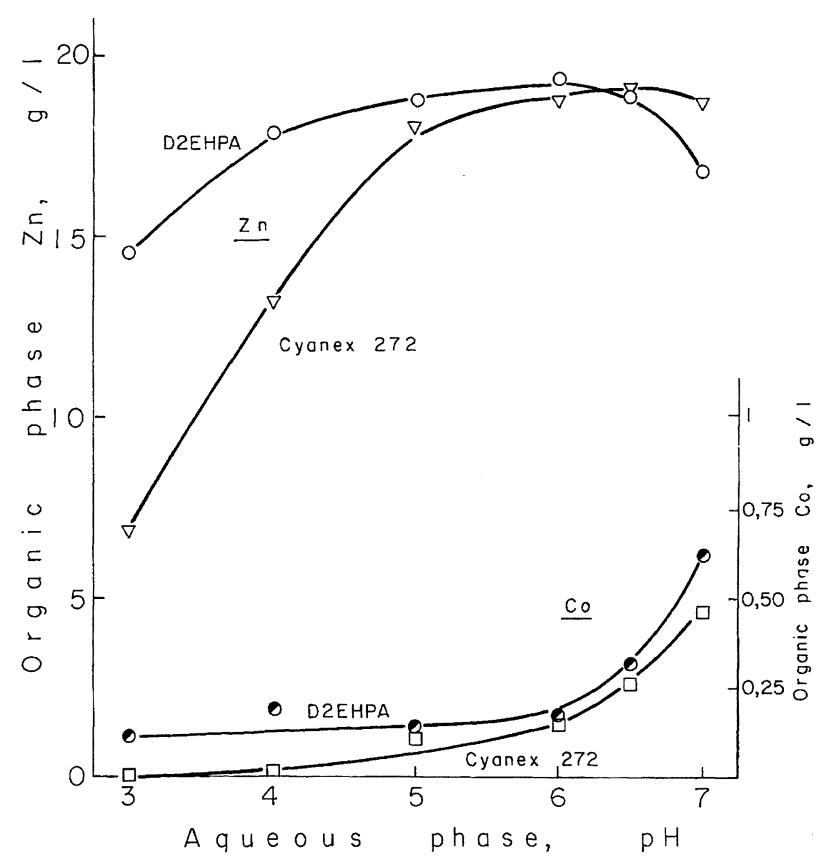

FIG. 8.- Extraction of zinc and cobalt by D2EHPA and Cyanex 272. Organic phase: 0.6 M extractant in kerosene 200/260 and $8 \%$ isodecanol. Initial aqueous phase composition: $\mathrm{Zn}=19.0 \mathrm{~g} / \mathrm{l}$, Co $=1.18 \mathrm{~g} / 1$ and $\mathrm{Cl}^{-}=174 \mathrm{~g} / \mathrm{l}$ in a concentrated ammonium chloride solution. $\mathrm{O} / \mathrm{A}$ phase ratio, $\sim 0.75 / 1$. Temperature, $50{ }^{\circ} \mathrm{C}$.

FIG. 8.- Extracción de cinc y de cobalto por D2EHPA y Cyanex 272. Fase orgánica: Extractante $\sim 0,6 \mathrm{M}$ en queroseno 200/260 y $8 \%$ de isodecanol. Composición inicial de la fase acuosa: $\mathrm{Zn}=19,0$ $\mathrm{g} / \mathrm{l}, \mathrm{Co}=1,18 \mathrm{~g} / \mathrm{l}$ y $\mathrm{Cl}^{-}=174 \mathrm{~g} / \mathrm{l}$ en una solución concentrada de cloruro amónico. Relación de fases O/A, 0,75/1. Temperatura, $50^{\circ} \mathrm{C}$.

negatively on the zinc extraction, because of the high stability of the aqueous zinc complexes with these ligands.

Many of the metals studied form high stable complexes with chloride $(\mathrm{Zn}, \mathrm{Cu}, \mathrm{Cd}, \mathrm{Pb}$ and $\mathrm{Hg}$ ) and/or ammonia ( $\mathrm{Zn}, \mathrm{Cu}, \mathrm{Cd}, \mathrm{Co}, \mathrm{Ni}$ and $\mathrm{Hg}$ ). Even for certain metals $(\mathrm{Zn}$ and $\mathrm{Cu}$ ) the simultaneous presence of a high chloride concentration and ammonia at high $\mathrm{pH}$ originates the formation of ternary complexes of the metal with both ligands (25 and 26). Ammonia complexes only are stable at high $\mathrm{pH}$, but stability of the chloride complexes is independent of $\mathrm{pH}$.

The presence of minor metal ions in the leaching solutions originates the simultaneous coextraction of these minor metals when zinc is extracted. This effect is more perceptible for D2EHPA than for Cyanex 272. Figures 4 to 9 and table II show the differences in the extraction of zinc and of the minor metal coextraction between the two extractants. Figure 4 shows the extraction of zinc,

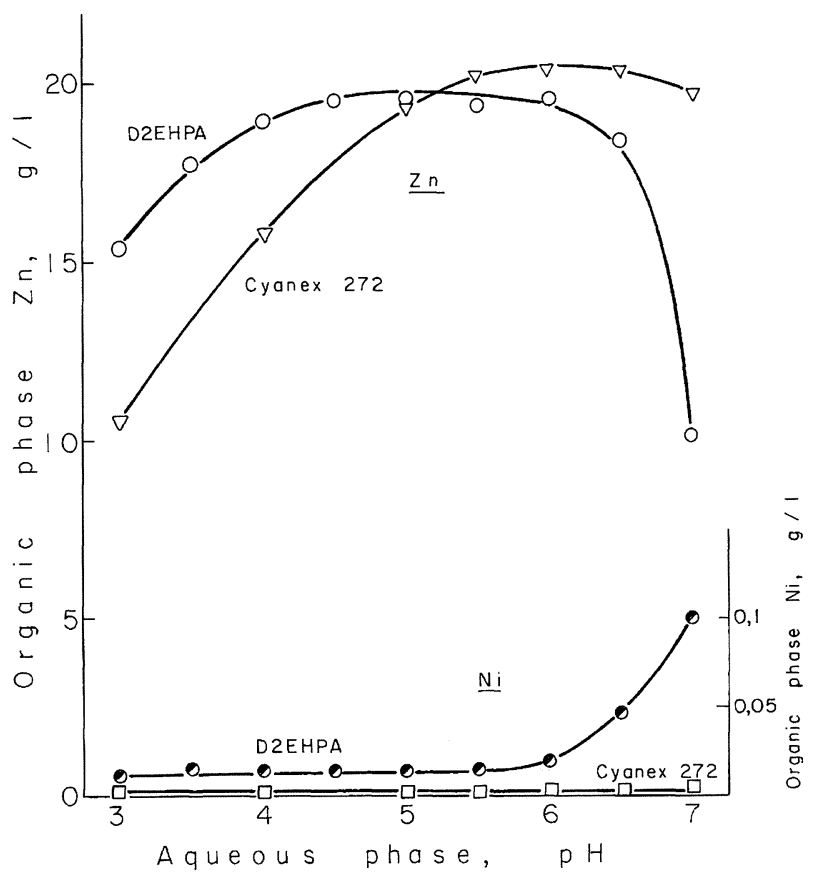

FIG. 9.- Extraction of zinc and nickel by D2EHPA and Cyanex 272. Organic phase: $\sim 0.6 \mathrm{M}$ extractant in kerosene 200/260 and $8 \%$ isodecanol. Initial aqueous phase composition: $\mathrm{Zn}=20.6 \mathrm{~g} / \mathrm{l}, \mathrm{Ni}$ $=0.95 \mathrm{~g} / 1$ and $\mathrm{Cl}^{-}=173 \mathrm{~g} / \mathrm{l}$ in a concentrated ammonium chloride solution. O/A phase ratio, $\sim 0.75 / 1$. Temperature, $50{ }^{\circ} \mathrm{C}$.

FIG. 9.- Extracción de cinc y de níquel por D2EHPA y Cyanex 272. Fase orgánica: Extractante $\sim 0,6 \mathrm{M}$ en queroseno 200/260 y $8 \%$ de isodecanol. Composición inicial de la fase acuosa: $\mathrm{Zn}=20,6$ $\mathrm{g} / \mathrm{l}, \mathrm{Ni}=0,95 \mathrm{~g} / \mathrm{l}$ y $\mathrm{Cl}^{-}=173 \mathrm{~g} / \mathrm{l}$ en una solución concentrada de cloruro amónico. Relación de fases $O / A, \sim 0,75 / 1$. Temperatura, $50^{\circ} \mathrm{C}$.

copper, lead and calcium from solutions of a similar composition to that of the actual complex sulphide leaching solutions. It can be observed a higher selectivity of Cyanex 272 for zinc with regard to calcium and copper, which are coextracted in a lesser extension than by D2EHPA. Lead coextraction is low for both extractants. This better selectivity of the Cyanex 272 is shown by most of the minor metals studied, but above all by calcium, which is the most coextracted metal by D2EHPA. Although there is some coextraction of these minor metals by D2EHPA from complex sulphide leaching solutions, for practical purposes, only the case of calcium is important, because lead is very little coextracted in the presence of zinc at higher concentrations up to a $\mathrm{pH} \sim 6$ and copper shows a minimum coextraction at this $\mathrm{pH}$. This is important because a $\mathrm{pH}$ about 6 is the $\mathrm{pH}$ existing in the aqueous phase in equilibrium with the loaded organic phase at the last extraction contact (second 
TABLA II.- Organic phase composition of the zinc and cadmium extraction by D2EHPA or Cyanex 272 from concentrated ammonium chloride solutions. Organic phase: $\sim 0.6 \mathrm{M}$ extractant in kerosene $200 / 260$ and $8 \%$ isodecanol. Initial aqueous phase composition: $\mathrm{Zn}=22.5 \mathrm{~g} / \mathrm{l}, \mathrm{Cd}=1.0 \mathrm{~g} / \mathrm{l}$ and $\mathrm{Cl}^{-}=174 \mathrm{~g} / \mathrm{l}$. Phase ratio O/A, $\sim 0.75 / 1$. Temperature, $50{ }^{\circ} \mathrm{C}$

TABLE II.-Composición de la fase orgánica en la extracción de cinc y de cadmio por D2EHPA o Cyanex 272 de soluciones concentradas de cloruro amónico. Fase orgánica: Extractante $\sim 0,6 \mathrm{M}$ en queroseno y $8 \%$ de isodecanol. Composición inicial de la fase acuosa: $\mathrm{Zn}=22,5 \mathrm{~g} / \mathrm{l}, \mathrm{Cd}=1,0$ g/l y $\mathrm{Cl}^{-}=174 \mathrm{~g} / \mathrm{l}$. Relación de fases O/A, 0,75/1. Temperatura, $50{ }^{\circ} \mathrm{C}$

\begin{tabular}{|c|c|c|c|c|c|}
\hline & \multicolumn{2}{|c|}{ D 2 E H P A } & & \multicolumn{2}{c|}{ Cyanex 272 } \\
\hline $\mathrm{pH}$ & $\mathrm{Zn} \mathrm{g/l}$ & $\mathrm{Cd}$ g/l & $\mathrm{pH}$ & $\mathrm{Zn} \mathrm{g/l}$ & $\mathrm{Cd} \mathrm{g} / \mathrm{l}$ \\
\hline 4.01 & 18.73 & 0.004 & 4.52 & 17.78 & 0.004 \\
\hline 5.02 & 19.53 & 0.001 & 5.03 & 19.10 & 0.004 \\
\hline 6.02 & 19.70 & 0.001 & 6.02 & 20.07 & 0.003 \\
\hline 6.99 & 17.97 & 0.01 & 6.99 & 19.70 & 0.004 \\
\hline
\end{tabular}

extraction stage) when both phases are separated in a continuous operation. In these conditions D2EHPA selectivity for zinc with regard to calcium is null, while Cyanex 272 shows a good $\mathrm{Zn} / \mathrm{Ca}$ separation.

As it has been indicated before, in the presence of a high concentration of chloride and ammonia high stable complexes of zinc and other metals with these ligands are formed. Calcium and magnesium do not form such complexes, so that calcium extraction is favoured in relation to that of zinc in the competence to be extracted by D2EHPA. Cyanex 272 shows a higher selectivity for zinc with regard to calcium and practically is not influenced by that effect and calcium extraction is much lower. Experimental tests show that calcium in the presence of zinc at higher concentrations is almost not extracted by Cyanex 272 at $\mathrm{pH} \sim 6$ and lower values. Only a minimum amount $(<10 \mathrm{mg} / \mathrm{l})$ is coextracted by Cyanex 272, while for D2EHPA this value at $\mathrm{pH} \sim 6$ is higher than $0.6 \mathrm{~g} / \mathrm{l} \mathrm{Ca}$. Figures 5 and 6 represent individual test results for copper and calcium respectively in the presence of zinc and confirm what has been said before. Copper extraction by D2EHPA shows anomalous results, because of the high stability of copper ammonia complexes, which at $\mathrm{pH} \sim 6$ allows only a minimum coextraction, while at lower $\mathrm{pH}(\sim 3.5)$ there is a maximum coextraction of copper.
Coextraction of the other minor metal ions in solution is higher at higher $\mathrm{pH}$ values of the solution. The leaching solutions, due to the presence of ammonia, show a slight increase of metal coextraction, and therefore a negative effect for the selectivity of zinc, which decreases when $\mathrm{pH}$ increases. Other minor metals examined present the same general trend that copper and calcium, Cyanex 272 has a higher selectivity for zinc than D2EHPA, with some exceptions. Figure 7 shows magnesium coextraction, which has a certain magnitude for D2EHPA, lower than that of calcium and which increases significantly at $\mathrm{pH}>6$. For Cyanex 272, also, there is coextraction of magnesium at the higher $\mathrm{pH}$ range, 6 to 7 , although at lower $\mathrm{pH}$ coextration decreases. Figure 8 represents cobalt coextraction, which at high $\mathrm{pH}$ increases for both extractants, but always keeps lower for Cyanex 272, and at low pH coextraction for this extractant is small. Cobalt coextraction with Cyanex 272 is higher than that of other divalent metals, as magnesium, calcium and nickel. Nickel (Fig. 9) and cadmium (Table II) show a minimum coextraction, almost negligible (only a few $\mathrm{mg} / \mathrm{l}$ ) for both extractants. Mercury, as it was said before, is not extracted from concentrated ammonium chloride solutions by none of the two extractants, probably because of the high stability of the mercury complexes with both, chloride and ammonia ligands.

Table III shows the separation factors of zinc in relation to the minor metal ions at $\mathrm{pH} \sim 6$, based on the results of the experimental work performed. As it has been said above, $\mathrm{pH} \sim 6$ is the value at which both phases are separated after the last extraction stage in a continuous operation. The separation factor, defined as the quotient of the distribution coefficients, $D_{Z n} / D_{M}$, is a measure of the selectivity of an extractant for a metallic ion with regard to other, when they are extracted. As it is observed in most of the cases the selectivity is higher for Cyanex 272 than for D2EHPA, with exceptions of cadmium and lead. In the case of cadmium metal concentrations in the organic phase are very small, only a few $\mathrm{mg} / \mathrm{l}$, which are of the same order of magnitude that the variation of the extracted metal concentration in the organic phase from one test to another. This means that the differences of selectivity between the two extractants could not be so significant as those shown in table III. For lead no binary tests have been performed and the values shown in table III were deduced from the two tests performed with solutions that, also, contained copper and calcium, as represented in figure 4 . In the case of calcium the values presented here confirm what was said before, that the selectivity of Cyanex 272 for zinc with regard to calcium is much higher than that of D2EHPA, which shows a 
TABLA III.- Separation factor of zinc with regard to the minor metals in solvent extraction of zinc by D2EHPA or by Cyanex 272 from concentrated ammonium chloride solutions at $\mathrm{pH}=6$. Organic phase: $\sim 0.6 \mathrm{M}$ extractant in kerosene $200 / 260$ and $8 \%$ isodecanol. Phase ratio $\mathrm{O} / \mathrm{A}, \sim 0.75 / 1$. Temperature, $50{ }^{\circ} \mathrm{C}$

TABLE III.-Factor de separación del cinc respecto de los metales minoritarios durante la extracción de cinc por D2EHPA o Cyanex 272 de soluciones concentradas de cloruro amónico a $\mathrm{pH}=6$. Fase orgánica: Extractante $\sim 0.6 \mathrm{M}$ en queroseno 200/260 y $8 \%$ de isodecanol. Relación de fases O/A $\sim 0,75 / l$. Temperatura, $50{ }^{\circ} \mathrm{C}$

\begin{tabular}{|c|l|l|lc|}
\hline Metals & $\begin{array}{l}\text { Separation } \\
\text { factor }\end{array}$ & Extractant & \multicolumn{2}{|l|}{$\begin{array}{l}\text { Initial } \\
\text { solution*, } \\
\text { g/l }\end{array}$} \\
\hline $\mathrm{Zn} / \mathrm{Cu}$ & 827 & Cyanex 272 & $\mathrm{Zn}$ & 23.4 \\
& 149 & D2EHPA** & $\mathrm{Cu}$ & 2.0 \\
\hline $\mathrm{Zn} / \mathrm{Ca}$ & 2800 & Cyanex 272 & $\mathrm{Zn}$ & 20.0 \\
& 0.19 & D2EHPA & $\mathrm{Ca}$ & 1.9 \\
\hline $\mathrm{Zn} / \mathrm{Mg}$ & 115 & Cyanex 272 & $\mathrm{Zn}$ & 18.8 \\
& 1.75 & D2EHPA & $\mathrm{Mg}$ & 1.0 \\
\hline $\mathrm{Zn} / \mathrm{Co}$ & 24 & Cyanex 272 & $\mathrm{Zn}$ & 19.0 \\
& 1.4 & D2EHPA & $\mathrm{Co}$ & 1.18 \\
\hline $\mathrm{Zn} / \mathrm{Ni}$ & 1.036 & Cyanex 272 & $\mathrm{Zn}$ & 20.6 \\
& 133 & D2EHPA & $\mathrm{Ni}$ & 0.95 \\
\hline $\mathrm{Zn} / \mathrm{Cd}$ & 1100 & Cyanex 272 & $\mathrm{Zn}$ & 22.5 \\
& 2450 & D2EHPA & $\mathrm{Cd}$ & 1.0 \\
\hline $\mathrm{Zn} / \mathrm{Pb}$ & 323 & Cyanex 272 & $\mathrm{Zn}$ & 21.4 \\
& 518 & D2EHPA & $\mathrm{Pb}$ & 2.4 \\
\hline
\end{tabular}

* Chloride concentration $=170-175 \mathrm{~g} / \mathrm{l}$. The $\mathrm{Zn} / \mathrm{Pb}$ solution also contained: $\mathrm{Cu} 2.5 \mathrm{~g} / \mathrm{l}$ and $\mathrm{Ca} 0.83 \mathrm{~g} / \mathrm{l}$.

** $\mathrm{Zn} / \mathrm{Cu}$ separation factor at $\mathrm{pH} 3.5$ (max. extraction of $\mathrm{Cu}$ with D2EHPA):

Cyanex $272=1.200$

$\mathrm{D} 2 \mathrm{EHPA}=4.7$

separation factor lower than unity at $\mathrm{pH} 6(\sim 0,2)$. This means that calcium is extracted better than zinc in the conditions of the test.

The Cyanex 272 behaviour in relation to its stability and solubility in the aqueous phase has been studied for the cobalt nickel separation process in sulphate solutions. The stability at $50{ }^{\circ} \mathrm{C}$ did not show any degradation after $142 \mathrm{~h}$ of treatment and its solubility in the aqueous phase was very low (about $2 \mathrm{ppm}$ ) (2) and also a low solubility is obtained in chloride solutions. These values are comparable to those of some other extractants used in metallurgical process plants, as D2EHPA. Therefore, it may be possible to use it in a process for the treatment of the leaching solutions as those of the CENIM-LNETI process. The high ionic concentrations in the solution, due to the high concentration of ammonium chloride, can help to keep low the solubility of the extractant in the aqueous phase. To this, a better selectivity of Cyanex 272 for the removal of calcium should be added.

Organic phases with a high load of extracted zinc have a high viscosity for both extractants, what should be taken into consideration with regard to the coalescence of the organic phase, which can be improved by increasing the temperature of the aqueous phase to $50{ }^{\circ} \mathrm{C}$. Also a modifier, as isodecanol, was added to the organic phase with this purpose. This high viscosity causes aqueous entrainment, and consequently chloride uptake, by the organic phase. This chloride retention by the organic phase can reach values of $1 \mathrm{~g} / \mathrm{l} \mathrm{Cl}^{-}$and higher for both extractants. To remove chlorides from the organic phase water washing contacts are effective and several stages are included in the flowsheet (17). Water was slightly acidulated $(\mathrm{pH}$ 2) with sulphuric acid. At a certain concentration chloride ions will be harmful for zinc electrolysis and it should be taken into account that in a continuous process the successive cycles extraction stripping will lead to impurity build up in the pregnant electrolite, unless impurities will be removed.

From all what has been explained before, it can be said that Cyanex 272 could be used for the zinc recovery and purification from leaching liquors such as those of the CENIM-LNETI process. The solvent extraction flowsheet would not be modified in relation to that of D2EHPA or will do only very little. However, it should be taken into consideration the incidence of the cost of the extractant on the process economy, that could be at present favourable to D2EHPA, because of its more extended use in metallurgical processes now in plant operation.

\section{CONCLUSIONS}

- Zinc extraction occurs with both extractants from concentrated ammonium chloride solutions. The $\mathrm{pH}$ range for zinc extraction with Cyanex is displaced in 0,5 to $1 \mathrm{pH}$ units to higher values with regard to those of D2EHPA.

- The organic phase composition in the case of zinc extraction by Cyanex 272 shows some differences with regard to that of D2EHPA, due to the presence of phosphine oxide impurities in Cyanex 272, which may form an adduct with zinc extraction species. 
- Cyanex 272 presents a higher selectivity for zinc extraction with regard to most minor metals impurities tested $(\mathrm{Ca}, \mathrm{Mg}, \mathrm{Cu}$ and $\mathrm{Co})$ than D2EHPA. This selectivity is very remarkable with respect to calcium impurity.

- Coextraction of lead, nickel and cadmium with both extractants is very low. Mercury is not extracted from concentrated ammonium chloride solutions by any one of the extractants, even when no zinc is present in solution.

- Cyanex 272 could be useful as an alternative extractant to D2EHPA in the CENIM-LNETI process.

\section{Acknowledgements}

The researchers gratefully acknowledge the DGICYT for its financial support in Project CE890016.

\section{REFERENCES}

(1) Handbook of Solvent Extraction. T.G. Lo, M.H. BAIRD and C. Hanson (Eds.). John Wiley, New York, 1983.

(2) Rickelton, W.A., Flett, D.S. and West, D.W. Solvent Extr. \& Ion Exch., 2 (6), 1984: 815-838.

(3) Xun, F. and Golding, J.A. Solvent Extr. \& Ion Exch. 5, 1987: 205-226.

(4) Rickelton, W.A. and Boyle, R.J. Sep. Sci. \& Technol. 23, 1988: $1227-1250$.

(5) PRESTON, J. Hydrometallurgy. 9, 1982: 115-133.

(6) Danesi, P.R., Reichler-Yinger, L., Mason, G., KaPlan, L., Horwitz, E.P. and Diamond, H. Solvent Extr. \& Ion Exch. 3 (4), 1985: 435.

(7) Yuan, C., Xu, Q., Yuan, S., Long, H., Shen, D., Jiang, Y., Feng, H., Wu, F. and Chen, W. Solvent Extr. \& Ion Exch. 6, (3) 1988: 393-416.
(8) Witte, M.K. and Frey, C. European Pat. Appl. O 154 448, 1985.

(9) Sabot, J.L. and Rollet, A. European Pat. 9156735 1985.

(10) Li, K. and Freiser, H. Solvent Extr. \& Ion Exch. 4 (4), 1986: 739-755.

(11) Komatsu, Y and Freiser, H. Anal. Chim. Acta, 227, 1989: 397-404.

(12) BAUER, D. et al. U.S. Pat. 4.559.203, 1985.

(13) Limpo, J.L., Figueiredo, J.M., Amer, S. and Luis, A. Hydrometallurgy, 28, 1992: 149-161.

(14) Limpo, J.L., Figueiredo, J.M., Amer, S. and Luis, A., Pat. Española 8.902.487, 1989, European Pat. Appl. 0434 831 A1, 1990

(15) Figueiredo, J.M., Novais, A.Q., Limpo, J.L. and Amer, S. Intern. Symp. World Zinc '93. The Australasian Institute of Mining and Metallurgy, Hobart, 1993: 333339.

(16) Limpo, J.L., Luis, A. and Gomez, C. Hydrometallurgy, 28, 1992: 163-178.

(17) Amer, S., Figueiredo, J.M. and Luis, A Hydrometallurgy, 37 (3), 1995: 323-337.

(18) Amer, S., Luis, A., Cuadra, A. and Caravaca, C., Rev Metal. Madrid. 30 (1), 1994: 27.

(19) Sella, C. and BAuer, D., Solvent Extr. \& Ion Exch., 6 (5), 1988: 819-833.

(20) A Technical Bulletin on DP-8R, Di(-2-ethylhexyl) phosphoric acid, Daihachi Chemical Industry Co. Ltd. № 381.

(21) Cobalt nickel separation using Cyanex 272. Preliminary Technical Brochure. American Cyanamid Co, July 1982.

(22) Morgan, S.W.K. Zinc and its Alloys and Compounds, J. Wiley, New York 1985.

(23) Amer, S., Luis, A. and Caravaca, C. $7^{\circ}$ Cong. Nnal. de Metalurgia. Madrid 1990. Vol 1: 291-298.

(24) Sastre, A.M., Miralles, N. and Figuerola, E. Solvent Extr. \& Ion Exch. 8 (4 \& 5), 1990: 597-614.

(25) LiMPO, J.L. and LuIs, A. Hydrometallurgy, 32, 1993: 247 260.

(26) Limpo, J.L., Luis, A. and Cristina, M.C. Rev. Metal. Madrid. 29 (1), 1993: 27-36. 